\title{
Correction to: Xanthohumol microbiome and signature in healthy adults (the XMaS trial): a phase I triple-masked, placebo-controlled clinical trial
}

Ryan Bradley ${ }^{1 *}$, Blake O. Langley ${ }^{1}$, Jennifer J. Ryan ${ }^{1}$, John Phipps ${ }^{1}$, Douglas A. Hanes ${ }^{1}$, Emily Stack', Janet K. Jansson², Thomas O. Metz ${ }^{2}$ and Jan Frederik Stevens ${ }^{3}$

Correction to: Trials (2020) 21:835

https://doi.org/10.1186/s13063-020-04769-2

Following publication of the original article [1], we were notified that in the first paragraph of the Interventions section (line 202), "Participants randomized to placebo will be administered $288 \mathrm{mg}$ of rice protein, 133.4 mg microcrystalline cellulose" should read "Participants randomized to placebo will be administered $288 \mathrm{mg}$ of rice protein,109.3 mg microcrystalline cellulose".

The original article has been corrected.

\section{Author details}

${ }^{1}$ National University of Natural Medicine, Portland, USA. ${ }^{2}$ Pacific Northwest National Laboratory, Richland, USA. ${ }^{3}$ Oregon State University, Corvallis, USA.

Published online: 26 October 2020

\section{Reference}

1. Bradley R, et al. Xanthohumol microbiome and signature in healthy adults

(the XMaS trial): a phase I triple-masked, placebo-controlled clinical trial.

Trials. 2020;21:835. https://doi.org/10.1186/s13063-020-04769-2.

The original article can be found online at https://doi.org/10.1186/s13063020-04769-2.

* Correspondence: rbradley@nunm.edu

${ }^{1}$ National University of Natural Medicine, Portland, USA

Full list of author information is available at the end of the article

(c) The Author(s). 2020 Open Access This article is licensed under a Creative Commons Attribution 4.0 International License, which permits use, sharing, adaptation, distribution and reproduction in any medium or format, as long as you give appropriate credit to the original author(s) and the source, provide a link to the Creative Commons licence, and indicate if changes were made. The images or other third party material in this article are included in the article's Creative Commons licence, unless indicated otherwise in a credit line to the material. If material is not included in the article's Creative Commons licence and your intended use is not permitted by statutory regulation or exceeds the permitted use, you will need to obtain permission directly from the copyright holder. To view a copy of this licence, visit http://creativecommons.org/licenses/by/4.0/. The Creative Commons Public Domain Dedication waiver (http://creativecommons.org/publicdomain/zero/1.0/) applies to the data made available in this article, unless otherwise stated in a credit line to the data. 